\title{
Foreword
}

\section{Baltic Association of Historians of Pedagogy: the First 20 Years}

The third collection of articles prepared by the Baltic Association of the Historians of Pedagogy (BAHP) is heading to its audience. The two previous collections were devoted to the overview of the history of education of the Baltic states until 1990, ${ }^{1}$ but this third book provides insight into the turbulent changes in education after the Baltic states regained independence in the 1990s until their entry into the European Union in 2004.

Thirty years ago, on 23 August 1989, two million Latvians, Lithuanians, and Estonians joined hands, uniting the capital cities of the Baltic states to proclaim a common goal - liberation from the Soviet Union and regaining of national independence. This event revitalised cooperation between the Baltic states, including universities and scholars. After regaining independence, it became relevant for historians of pedagogy (education) to unite in an organisation that could strengthen networking between the leading scholars that had already begun in the 1970s.

The Baltic Association of the Historians of Pedagogy was founded in 1999 with headquarters in Riga and three branches in Latvia, Lithuania, and Estonia. Prof., Dr. habil. paed. Leonards Žukovs (1922-2019), was the initiator and founder of the Association. Until 2010, Žukovs was the Board Chair and Honorary Chair until the end of his life. Several significant Baltic historians of pedagogy, members of BAHP, have passed away in recent years. Lembit Andresen (1929-2016), Maria Tilk (1948-2015) and Vello Paatsi (1948-2015) are with us no longer.

Gratitude for organizing the activities of the Lithuanian branch over the last decade should be expressed to Vidimantas Raudys (Klaipeda University) and for management of the Estonian branch to Vadim Rouk and Veronika Varik (Tallinn University). Since the founding of BAHP, Romāns Alhimionoks, owner of the education literature publishing house $\mathrm{RaKa}$, has been actively involved in the life of the Association: he has been the patron of all previous BAHP publications, collections of articles, conference programmes, and other printed

\footnotetext{
A. Krūze, I. Ķestere, V. Sirk, O. Tijūneliene (eds.), History of Education and Pedagogical Thought in the Baltic Countries up to 1940: an Overview, Riga, RaKa, 2009; I. K̦estere, A. Krūze (eds.), History of Pedagogy and Educational Sciences in the Baltic Countries from 1940 to 1990: an Overview, Riga, RaKa, 2013.
} 
materials. It should be mentioned that the Latvian Academy of Sport Education and the University of Latvia have also been BAHP supporters for many years.

Much has been achieved through joint efforts between historians of pedagogy from Latvian higher education institutions, scholars from Klaipeda and Vilnius Universities (Lithuania), and Tallinn and Tartu Universities (Estonia). International conferences have been organised on a regular basis in each BAHP branch and conference proceedings on current research in the history of pedagogy were published; for example, Reformpädagogik and the Baltics (2003), Research in the History of Pedagogy in the Baltic States (2004), and Pedagogy in the Changing Historical Conditions of the $20^{\text {th }}$ Century in the Baltic Countries (2009).

In 2011, the $800^{\text {th }}$ anniversary of Riga Dom School was celebrated with an extensive programme and a collection of articles, Origins of Riga Dom School and Education in the Baltics, depicting the history of Dom schools in Riga and Tallinn as well as development of the first schools in Lithuania. In 2013, BAPH was honoured to fulfil the responsible duty of organizing the $35^{\text {th }}$ International Standing Conference for the History of Education (ISCHE) 'Education and Power: Historical Perspectives' at the University of Latvia. ISCHE 35 was attended by 226 delegates from 103 universities in 38 countries. In 2017, an international conference at the University of Latvia, 'Reformation in the Modern World', was devoted to the $500^{\text {th }}$ anniversary of the Reformation at which a panel discussion, 'Reformation for Education and Upbringing', was organised in cooperation with BAPH. In 2018, BAHP supported the $9^{\text {th }}$ History of Education Doctoral Summer School (HEDSS-9) at the University of Latvia, bringing together new scholars and experts from 16 countries.

Employees from various Baltic museums are involved in BAHP, encouraging focus on museology and museum pedagogy. Museum experience was gained at Baltic universities and school museums as well as the Leipzig School Museum; in 2017, BAHP organised an international conference in cooperation with the Ventspils City Museum.

What we have gained from this extensive and successful cooperation effort? Academic and scientific networking has promoted interest and understanding about the Baltic states in the framework of European history of pedagogy; various forms of cooperation and joint studies have contributed to the content and methodology of pedagogy history research; regular meetings and experience exchanges have given new impetus for transformation processes in schools, universities, and museums; and interest in research and a 20-yearlong friendship promises to stimulate future cooperation among the young generation of historians of pedagogy.

The purpose of BAHP's third book is to provide research-based articles about turbulent changes in education after the Baltic states regained independence. Historical review reveals the complexity of the post-1980s. The four sections demonstrate the various interests of historians of pedagogy, and their choice of topics reflect current studies and scope of activity. In total, changes in the history of education in the Baltic states are comparable: democracy meant 
development of new laws and regulations in education, creation of new study programmes and curricula, and preparation and publishing of textbooks and teaching/learning aids. However, a review and comparison of results achieved in pedagogy and educational sciences during the last 30 years indicate that each country also has its own specific traits that may seem interesting to BAHP members.

I would like to express my gratitude to all the contributors, but especially editors Iveta Kestere, Ene-Silvia Sarv, Irena Stonkuviene, and Aija Abens, as we would not be able to publish this collection without their determined efforts.

Board Chair

Baltic Association of the Historians of Pedagogy

Prof. emeritus, University of Latvia, Dr. paed. Aīda Krūze 